\title{
Improving students' vocabulary mastery through crossword puzzle at the first grade of SMPN 14 Bandarlampung
}

\author{
Selvi Destiana ${ }^{1}$, Ujang Suparman'2, Huzairin ${ }^{3}$ \\ FKIP Universitas Lampung, Jl. Prof. Dr. Soemantri Brojonegoro No. 1 Bandarlampung ${ }^{1,2,3}$ \\ Correspondence: selvidestiana02@gmail.com
}

\begin{abstract}
The objective of this research is to find out whether there is a significant difference of the students' vocabulary mastery before and after being taught through crossword puzzle and also to find out which content of word that improves the most. The study was a quantitative research which used one group pre-test and post-test design. The population of this research was 337 students of the first grade students of SMPN 14 Bandar Lampung in academic year 2018/2019. The subject is consisting of 155 male students and 182 female students. The average age of the first grade students is 12 years old. The sample of this research was taken randomly. The class of VII $\mathrm{F}$ is chosen as the sample of this research and the class consists of 31 students. A vocabulary test was used to collect the data. The result of students' vocabulary test was measured in terms of noun, verb, adjective and adverb. The data were analyzed by using Repeated Measures t-test (SPSS) in which the significance was determined by $p<0.05$. The result of this research shows that the value of significance is 0.000 . It means that $\mathrm{H}_{1}$ is accepted and $\mathrm{H}_{0}$ is rejected since the $p$ score is lower than 0.05. Based on the result, it can be concluded that there is a significant difference of the students' vocabulary mastery before and after being taught through crossword puzzle. Furthermore, the finding also shows that noun has the highest gain with the percentage $35 \%$. The mean of noun in the pretest score is 22.1 and the mean of noun in the posttest score is 26.4. From the explanation above, crossword puzzle is recommended to be applied in teaching and learning vocabulary since the result shows positive effect to students.
\end{abstract}

Keywords: vocabulary, content words, crossword puzzle

\section{INTRODUCTION}

Vocabulary is one of crucial aspects in English. As stated by Richard and Renandya (2002), vocabulary is a core component of language proficiency that provides much of the basis of how well learners speak, listen, read and write. Vocabulary mastery will affect someone's ability in using the language either in spoken or written form. A learner who just learns grammar without learning vocabulary will get difficulties in understanding the text, communicating with other people, expressing and writing their own ideas. Vocabulary is needed to improve four English skills, namely listening, speaking, reading, and writing. This means that vocabulary plays an important role in the field of study. Students who have a sufficient vocabulary will be able to communicate or express themselves clearly and effectively.

In fact, most of EFL students often get difficulties in learning English because they have low vocabulary. Based on the interview with an English teacher in SMPN 14 Bandar Lampung, students face many problems in mastering vocabulary. The problems are students were still confused in remembering words and they were unmotivated to learn English. It is supported by the previous research by Nurhamida (2012). She conducted a research at the first grade students 
of SMP N 2 Tuntang. She found that the problems faced by students dealing with vocabulary. The problems are many students get the difficulty in remembering new vocabulary and also they are not interested in learning English.

From the problems above, the researcher assumed that it is necessary for English teachers to choose and apply good media which are interesting and also meaningful. To overcome the problems faced by students, the researcher decided to do further action to overcome those problems by implementing appropriate media to teach vocabulary. There are many kinds of media, such as pictures, crossword puzzle game, songs, riddle, etc. Therefore, in this research the researcher intended to implement crossword puzzle to help students in increasing their vocabulary mastery.

In this case, the researcher implemented crossword puzzle to improve student's vocabulary mastery. Thus, by using the crossword puzzle, the researcher expects the students have pleasure atmosphere in learning English and help them to improve their vocabulary mastery. According to Raines (2010), he states that one major advantage of using crossword puzzle as teaching instruction is that most students associate crossword puzzles with game playing and recreation. Dhand (2008), different kinds of benefits for using crossword puzzles included, it is as a fun and raise students' motivation, it can be easily made by the teacher and even the students themselves, encourage the use of dictionary and can be used for different types of classroom activities. Moreover, Paul (2004) said that crossword puzzles can be used at any level and they are a wonderful way to teach vocabulary from many different lessons. So, the researcher is interested in applying crossword puzzle to improve students' vocabulary mastery at the first grade students of SMPN 14 Bandar Lampung.

To support this study, there are several studies on crossword puzzle in vocabulary mastery. First, the use of crossword puzzle in teaching vocabulary was done by Damai (2011) at SMPN 2 Tegalsari Banyuwangi. He found that the use of crossword puzzle could improve the students' vocabulary achievement from $75.5 \%$ to $78.6 \%$. Second research was conducted by Trisna (2014) at SMPN 2 Rambipuji Jember, he also found that the use of crossword puzzle could improve the students' vocabulary achievement from $63.88 \%$ to $83.33 \%$. The next previous research was done by Orawiwatnakul (2013). The result revealed that learning vocabulary through crosswords for Thai students is one of the best ways to improve their vocabulary. It is effective for students in learning vocabulary through crossword puzzle. (Njoroge, Ndung'u and Gathigia, 2013).Those conclude that crossword puzzle can be implemented to increase students' vocabulary mastery.

Based on the problems and the reasons, The researcher were interested to investigate whether: (1) there was a difference of the students' vocabulary mastery after being taught through crossword puzzle; and (2) which content word of vocabulary improves the most after they are taught through crossword puzzle game.

\section{METHODS}

The research' sample was one class of 31 students in SMPN 14 Bandar Lampung in academic year 2018/2019 who had problems in vocabulary and the researcher implemented crossword 
puzzle aimed to improve the students' vocabulary mastery. The quantitative data was used in order to collect the data after implemented the crossword puzzle. The design in this research was one group pre-test and post-test. The researcher used one class where the students received pre-test before treatments and they received post-test after the treatments. For the data collection instruments, the researcher used pretest and posttest for vocabulary tests. The pretest was applied after conducting a try out test. The test was in written form of multiple choice consisted of 40 questions in 60 minutes. The posttest was administered after the treatments which the questions was re-arranged in pre-test. In SPSS, a paired simple t-test was used to determine the differences among pretest and posttest.

\section{RESULTS AND DISCUSSIONS}

\section{Results}

The researcher used Picture series technique to find out there was an improvement in vocabulary mastery. In the beginning whether of this activity, the pre-test was administered to investigate the reading comprehension achievement before being given treatments. The total score of pre-test was 2105; the mean score of pretest was 67.90; the highest score was 80.00 ; the lowest score was 53.00. From the result of the test, 6 students who get score higher than 75 . There are 6 students who get score 73 and 4 students score 70 . And the rest 15 students' score lower than 70. The result showed that most of the students' scores were lower than minimal mastery criterion (KKM) in SMPN 14 Bandar Lampung which required the students to get 70. It indicated that the students' vocabulary mastery was poor.

After the treatments in three meetings using crossword puzzle, the researcher administered post-test to know whether there is a difference of the students' vocabulary mastery or not. The results showed that the total score of post-test was 2415; the mean score was 77.90; the highest score was 90.00; and the lowest score was 70.00.

Table 1. The Analysis of the Hypothesis Testing Paired Differences

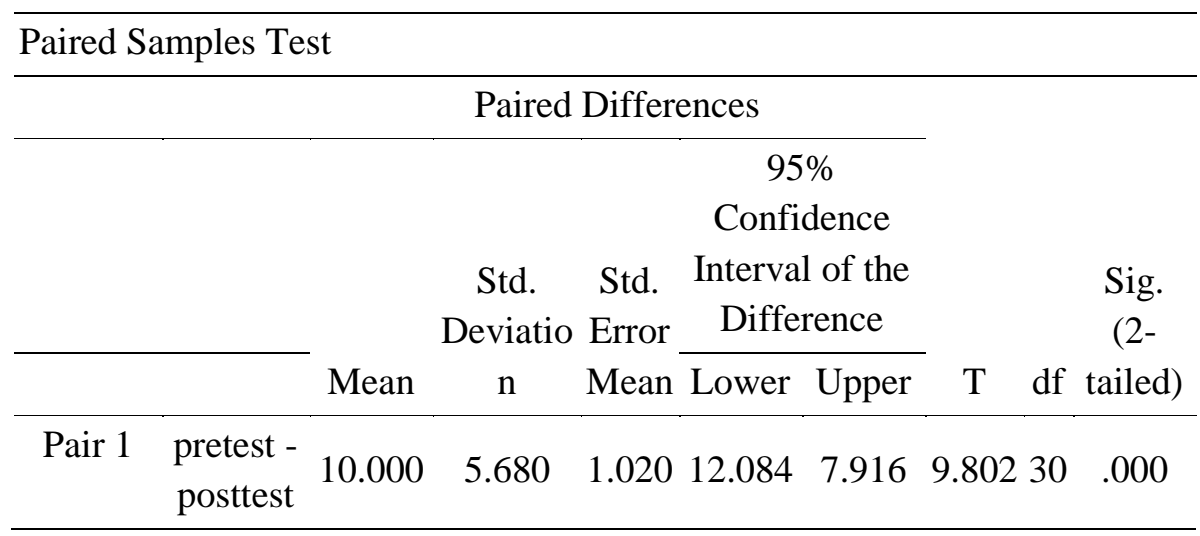

Based on Table 1 above, it can be seen that the result of t-test shows that t-value is 18.067and the two tail significant show that $\mathrm{p}<0.05$ ( $\mathrm{p}=.000$ ). It can be inferred that $\mathrm{H}_{1}$ is accepted and $\mathrm{H}_{0}$ is rejected since $0.000<0.05$. In conclusion, there is a significant difference of students' reading comprehension ability of narrative text before using the picture series technique and after using the picture series technique. Thus, the hypothesis is accepted. 
From the result vocabulary test in a pre-test and a post-test, it can be inferred that there was an improvement of the students' vocabulary mastery after the implementation of crossword puzzle. The mean score of pre-test was 67.90 , increased to 77.90 in the post-test. So the gain was 10.00 . Moreover the researcher found out the improvement of each aspect, it could be seen in table below:

Table 2The Increase of Students' Mastery of Each Type of Content Words

\begin{tabular}{cccccc}
\hline No & $\begin{array}{c}\text { Type of } \\
\text { Content Words }\end{array}$ & $\begin{array}{c}\text { Mean Score } \\
\text { of Pre-Test }\end{array}$ & $\begin{array}{c}\text { Mean Score } \\
\text { of Post-test }\end{array}$ & Gain & Percentage \\
\hline 1 & Noun & 22.1 & 26.4 & 4.3 & $35 . \%$ \\
\hline 2 & Adjective & 19.7 & 23 & 3.3 & $26.8 \%$ \\
\hline 3 & Verb & 21.4 & 23.8 & 2.4 & $19.5 \%$ \\
\hline 4 & Adverb & 20.7 & 23 & 2.3 & $18.6 \%$ \\
\hline & Total & 83.9 & 96.2 & 12.3 & $100 \%$ \\
\hline
\end{tabular}

Table 2 shows that the average score of the students' who answered correctly of the aspect of vocabulary, Nouns improves from 22.1 in the pretest to 26.4 in the posttest. The average gain from pretest and posttest is 4.3. For the second aspect, adjective improves from 19.7 in the pretest to 23 in the posttest. The average gain score pretest and posttest is 3.3. Then, for the third aspect, which is verbs improves from 21.4 in the pretest to 23.8 in the posttest. The average gain score from pretest and posttest is 2.4. The last aspect, which is adverb, improves from 20.7 in the pretest to 23 in the posttest. The average gain score from the pretest and the posttest is 2.3 . Based on the result of the improvement of students' vocabulary mastery for each aspect of vocabulary, it was found that the aspect got the highest improved was a noun. It improved from 22.1 in the pretest to 26.4 in the posttest. Then, the aspects that had the lowest score were adverb. It improved from 20.7 in the pretest to 23 in the posttest.

\section{Discussions}

The purposes of the research are to find out whether there is a difference of the students' vocabulary mastery after being taught through crossword puzzle and which content word of vocabulary improves the most after they are taught through crossword puzzle game. The students' score of pre-test and post-test were compared to determine the students' improvement. The result showed that there was an increase between the students' mean score in the pre-test to the post-test. It implies that crossword puzzle has a positive effect of the students' vocabulary mastery. This supports the previous research that was conducted by Utami (2014). She found that the students' vocabulary mastery was improved through the implementation of crossword puzzle. It means that the improvement between the students' mean score in the pre-test to posttest.

Referring to the result of data analysis, the researcher shows that there are fifteen students who got score less than English's minimal mastery criterion (KKM. In the post-test, there was no student who got score less than English's minimal mastery criterion (KKM). There was an 
increase between the students' mean score in the pre-test to the post-test. On the other hand, the researcher did not only analyze the improvement of the students' vocabulary mastery, but it also included the increase in content word of vocabulary. So, this makes the result of the research deeper and more specific. The result of this research shows that all content words of vocabulary were improved, those are noun, followed by adverb, verb, and adjective.

Nouns are the content word improved the most. It is supported by Ellis and Beaton (1993). They stated that in learning new words, nouns are probably the easiest part of speech to learn, followed by adjectives, verbs and adverbs. It means that nouns are the easiest content word among the others. In contrast, according to Faransari (2011), adverb became the lowest content word. She found that adverbs were the most difficult words to understand. In her research, it was found that adverb type was the only type which did not get any improvement. It was caused by the limitation of the material which included adverbs.

This research has proven that the use of crossword puzzle could increase the students' vocabulary mastery. This finding supports the research finding of Lesmono (2010) entitled, "Using Crossword Puzzles to Improve the Vocabulary Mastery of the First Grade Student at SLTP 1 Tanjungsari, Yogyakarta". Crossword Puzzle enabled the students to be more familiar with the words and memorized the words easily because they played Crossword Puzzle in the learning process. Playing Crossword Puzzle attend the words for several times. Crossword puzzle could be one of the interesting media in teaching and learning vocabulary. It is supported by Jaramillo and Losada (2012), students found designing crosswords not only a useful and creative activity but also an exciting opportunity to self-assess their learning. Students were aware of the improvement in their knowledge using crossword puzzles as a learning tool. It is also beneficial in learning theoretical knowledge, making the classroom experience more enjoyable. Therefore, Crossword Puzzle can be used as a great media in teaching learning vocabulary in classroom.

\section{CONCLUSIONS AND SUGGESTIONS}

Referring to the results of the data analysis, the researcher concluded that there was a significant difference of the students' vocabulary mastery after being taught through crossword puzzle at the first grade of SMPN 14 Bandar Lampung. It can be seen from the result of the hypothesis testing which shows that a significant level was higher than t-table. The students' mean score in the post-test was higher than in the pre-test. It means that there was an increase between the students' mean score in pre-test and post-test. It can be concluded that crossword puzzle can be used to improve students' vocabulary mastery. It happened because crossword puzzle helped students to improve their vocabulary mastery. The highest improvement is noun followed by adverb, verb, and adjective. This is showed that noun is the content word that improved the most among the other content words since the students mostly finds those words in daily life.

Suggestions for the Teacher, in implementing crossword puzzle game in teaching vocabulary, the teacher should give a copy of crossword puzzle and explains the rules such as students have to complete it as quickly as possible. The students who can complete it first will get a reward from the teacher. It makes this game becomes more attractive. Suggestions for the further researcher, to avoid the limitation of the time, further researchers should explain the rules of 
crossword puzzle loudly and clearly or they should explain how to play crossword puzzle by showing a short video recorder, so the students paid attention to the teacher and understand the crossword puzzle well.

\section{REFERENCES}

Damai, I. M. 2011. The use of crossword puzzles to improve the eight year students' vocabulary achievement at SMPN 2 Tegalsari Banyuwangi in the 2010/2011 Academic Year. Jember: Universitas Jember (Unpublished Thesis).

Dhand, H. 2008. Techniques of teaching. New Delhi: APH Publishing Corporation.

Ellis, N., \& Beaton. 1993. Psycholinguistic determinants of foreign language vocabulary learning. Language Learning, Vol.43, pp: 559-617.

Faransari, M. E. 2011. Increasing students' vocabulary achievement through clustering technique at the first year of SMA Gajah Mada Bandar Lampung. Undergraduate (S1) script,Bandar Lampung: Universitas Lampung.

Jaramillo, C. M. Z., \&Losada, B. M. 2012. Designing and solving crossword puzzles: Examining efficacy in a classroom exercise. Developments in Business Simulation and Experiential Learning, P.213-222.

Lesmono, Andi. 2010. Using crossword puzzles to improve the vocabulary mastery of the first grade students at SLTP 1 Tanjungsari, Yogyakarta. Yogyakarta, Thesis FBS.

Njoroge, M. C., Ndung'u, R. W., \& Gathigia, M. G. 2013. The use of crossword puzzle as a vocabulary learning strategy: A case of English as second language in Kenya Secondary School, (International Journal of Current Research, Vol 5, Issue 02, pp.313 321, February, 2013),p. 2.

Nurhamida, D. 2012. The effectiveness of crossword puzzle in learning vocabulary (A quasyexperimental study at the seventh grade students of MTS. Muhammadiyah 1 Ciputat). Unpublished Script. Jakarta: SyarifHidayatullah State Islamic University.

Orawiwatnakul, W. 2013.Crossword puzzles as a learning tool for vocabulary development. Electronic Journal of Research in Educational Psychology, Vol. 11, pp: 413-428.

Paul, D. 2004. Teaching English to children in Asia. Hongkong: Longman AsiaELT.

Raines, D. A. 2010. An innovation to facilitate student engagement and learning: Crossword puzzles in the classroom. Teaching and Learning in Nursing. Vol. 5, pp: 85-90.

Richard, J. C., \&Renandya, W. A. 2002. Methodology in language teaching: An anthology of current practice. Cambridge: Cambridge University.

Trisna, M. 2014. Improving the eight year students' vocabulary achievement and their active participation by using Crossword Puzzle at SMPN2Rambipuji: UniversitasJember.

Utami, Y. S. 2014. Improving students' vocabulary mastery using Crossword Puzzles for grade VII of SMPN2 Srandakaninthe academic year of 2013/2014. Yogyakarta: Universitas Negeri Yogyakarta. 